\title{
Vibrio cholerae interactions with Mytilus galloprovincialis hemocytes mediated by serum components
}

\author{
Laura Canesi ${ }^{1}$, Elisabetta Pezzati ${ }^{1}$, Monica Stauder ${ }^{1}$, Chiara Grande $^{1}$, Margherita Bavestrello ${ }^{1}$, \\ Adele Papetti ${ }^{2}$, Luigi Vezzulli ${ }^{1}$ and Carla Pruzzo ${ }^{1}$ *
}

${ }^{1}$ Dipartimento di Scienze della Terra, dell'Ambiente e della Vita, Università di Genova, Genova, Italy

2 Dipartimento di Scienze del Farmaco, Università di Pavia, Pavia, Italy

\section{Edited by:}

Daniela Ceccarelli, University of Maryland, USA

Reviewed by:

Spencer V. Nyholm, University of Connecticut, USA

Gian Marco Luna, National Research

Council - Institute of Marine

Sciences, Italy

*Correspondence:

Carla Pruzzo, Dipartimento di Scienze della Terra, dell'Ambiente e della Vita, Università di Genova, Corso Europa 26, 16132 Genova, Italy e-mail: carla.pruzzo@unige.it
Edible bivalves (e.g., mussels, oysters) can accumulate large amount of bacteria in their tissues and act as passive carriers of pathogens to humans. Bacterial persistence inside bivalves depends, at least in part, on hemolymph anti-bacterial activity that is exerted by both serum soluble factors and phagocytic cells (i.e., the hemocytes). It was previously shown that Mytilus galloprovincialis hemolymph serum contains opsonins that mediate D-mannose-sensitive interactions between hemocytes and Vibrio cholerae 01 El Tor bacteria that carry the mannose-sensitive hemagglutinin (MSHA). These opsonins enhance phagocytosis and killing of vibrios by facilitating their binding to hemocytes. Since $V$. cholerae strains not carrying the MSHA ligand (O1 classical, non-O1/O139) are present in coastal water and can be entrapped by mussels, we studied whether in mussel serum, in addition to opsonins directed toward MSHA, other components can mediate opsonization of these bacteria. By comparing interactions of $\mathrm{O} 1$ classical and non01/0139 strains with hemocytes in artificial sea water and serum, it was found that $M$. galloprovincialis serum contains components that increase by at approximately twofold their adhesion to, association with, and killing by hemocytes. Experiments conducted with high and low molecular mass fractions obtained by serum ultrafiltration indicated that these compounds have molecular mass higher than $5000 \mathrm{Da}$. Serum exposure to high temperature $\left(80^{\circ} \mathrm{C}\right)$ abolished its opsonizing capability suggesting that the involved serum active components are of protein nature. Further studies are needed to define the chemical properties and specificity of both the involved bacterial ligands and hemolymph opsonins. This information will be central not only to better understand $V$. cholerae ecology, but also to improve current bivalve depuration practices and properly protect human health.

Keywords: Vibrio cholerae, adherence, mussel, hemocytes, serum

\section{INTRODUCTION}

Microorganisms in seawater can be entrapped by filter feeding invertebrates that sieve suspended particles from the aquatic environment (Vazquez-Novelle etal., 2005; Beleneva et al., 2007). Accumulation of bacteria pathogenic to humans in the tissues of edible bivalves is of great concern to public health; in fact, consumption of raw or inadequately cooked bivalves has been implicated in numerous food poisoning outbreaks (Suzita et al., 2009; Scallan etal., 2011). Bivalve microbiological depuration (purification) in controlled waters is used worldwide to reduce the number of unwanted microorganisms to acceptable levels for human consumption (Teplitski et al., 2009). However, bacteria show different sensibility to depuration treatment; for instance, some Vibrio species have been reported to be resistant to the process and are able to persist and multiply within shellfish tissues (Tamplin and Capers, 1992; Murphree and Tamplin, 1995).

A relationship between microbial resistance to depuration and sensitivity to hemolymph bactericidal activity has been suggested (Harris-Young etal., 1995; Canesi etal., 2002, 2005). Shellfish hemolymph contains both hemocytes, which are responsible for cellular defense mechanisms (i.e., phagocytosis, production of reactive oxygen intermediates, and release of lysosomal enzymes), and soluble factors (e.g., opsonizing lectins and hydrolytic enzymes; Canesi etal., 2002; Pruzzo etal., 2005a). The capacities of different bacteria to survive hemolymph microbicidal activity depend on their sensitivities to combinations of these factors (Duperthuy et al., 2011; Balbi et al., 2013). Elucidation of underlying molecular mechanisms is crucial to improve current depuration practices and properly protect human health.

Vibrio cholerae is part of the endogenous bacterial component in estuarine areas (Kaper et al., 1995; Lipp et al., 2002). Only two serogroups, O1 (classical and El Tor biotypes) and O139 have been associated with cholera epidemic disease although nearly 200 serogroups of $V$. cholerae (named "non-O1/O139") have been described (Kaper et al., 1995; Nelson et al., 2009). The great majority of non-O1/O139 strains do not produce cholera toxin and are not associated with epidemic diarrhea. These strains are much more commonly isolated from the environment than are O1/O139 strains, and are occasionally isolated from cases of diarrhea usually due to consumption of raw or 
partially cooked shellfish (Iwamoto etal., 2010; Oliver etal., 2013).

Recent data on surface components involved in interactions of V. cholerae O1 with hemocytes of Mytilus galloprovincialis, an economically important, and appreciated seafood in the Mediterranean area, indicated that hemolymph serum contains opsonins specifically directed toward the "mannose-sensitive hemagglutinin (MSHA)" (Zampini et al., 2003), an adhesin expressed by El Tor and $\mathrm{O} 139$ strains (other V. cholerae strains either do not carry the msha gene or do not express it, i.e., strains of O1 serogroup, classical biotype; Chiavelli et al., 2001). It was suggested that Dmannose containing serum opsonins, capable to specifically react with MSHA, are involved in V. cholerae El Tor phagocytosis, and killing by mussel hemocytes (Zampini et al., 2003).

However, the above data did not rule out the possibility that in mussel serum, in addition to opsonins directed toward MSHA, other components are present that mediate interactions with hemocytes of vibrios different from O1 El Tor. To explore this possibility, we tested the capability of M. galloprovincialis serum to promote phagocytosis and killing by hemocytes of $V$. cholerae bacteria of $\mathrm{O} 1$ classical biotype and non-O1/O139 serogroups. The obtained results indicate that opsonizing molecules directed toward these bacteria are actually present in M. galloprovincialis hemolymph serum; a preliminary analysis of these components and the involved bacterial antigens is presented.

\section{MATERIALS AND METHODS BACTERIA AND CULTURE CONDITIONS}

Vibrio cholerae CD81 (O1 classical) was kindly provided by Dr. B. S. Srivastava (Microbiology Division, Central Drug Research Institute, Lucknow 226001, India); RC60, RC66, and RC69 (non-O1/O139) were kindly provided by Dr. A. Huq (Maryland Pathogen Research Institute, University of Maryland, College Park, MD 20742, USA). N16961 ATCC ${ }^{\circledast} 39315^{\mathrm{TM}}$ (O1 El Tor) was also used in some experiments. All cultures were grown in Luria-Bertani (LB) broth or agar under static conditions at $37^{\circ} \mathrm{C}$. To radiolabel bacteria, strains were grown overnight in LB broth containing $10 \mu \mathrm{Ci}$ of [methyl- $\left.{ }^{3} \mathrm{H}\right]$ thymidine $(25 \mathrm{Ci} / \mathrm{mmol}) \mathrm{ml}^{-1}$, were then harvested by centrifugation $(3,000 \times g$ for $15 \mathrm{~min}$ at $4^{\circ} \mathrm{C}$ ), washed three times with phosphate-buffered saline (PBS; $\left.0.1 \mathrm{M} \mathrm{KH}_{2} \mathrm{PO}_{4}, 0.1 \mathrm{M} \mathrm{Na}_{2} \mathrm{HPO}_{4}, 0.15 \mathrm{M} \mathrm{NaCl}, \mathrm{pH} 7.2-7.4\right)$, and resuspended in PBS at an $\mathrm{A}_{650}$ of $1\left(2 \times 10^{8}\right.$ to $4 \times 10^{8}$ bacteria $\left.\mathrm{ml}^{-1}\right)$. The number of counts per minute (cpm) per milliliter and the number of bacteria per milliliter were evaluated in triplicate samples to calculate the efficiency of cell labeling (number of bacteria per cpm) that varied in different bacterial preparations from 180 to 350. Artificial sea water [ASW; 35\%o (wt/vol) salinity, pH 7.9], filtered onto $0.22 \mu \mathrm{m}$-pore-size Millipore filters (Bedford, MA, USA), was used throughout the experiments.

\section{PREPARATION OF MUSSELS HEMOCYTE MONOLAYERS}

Mussels (M. galloprovincialis Lam.) were obtained from the depuration plant Casa del Pescatore (Cattolica, Italy). Animals were transferred to the laboratory, cleaned of epibiota and kept in an aquarium at $16^{\circ} \mathrm{C}$ in static tanks containing ASW (1 1/animal) for 1-3 days before use; sea water was changed daily. Hemolymph was extracted from the posterior adductor muscle of the mussels by using a sterile $1 \mathrm{ml}$ syringe with a 18 -gauge, 0.5 -in. long needle. After the needle was removed, the hemolymph was filtered through sterile gauze and pooled. To prepare hemocyte monolayers, an approximately $0.3-\mathrm{ml}$ portion of hemolymph (corresponding to about $2 \times 10^{6}$ to $3 \times 10^{6}$ cells) was seeded onto glass coverslips ( 20 by $22 \mathrm{~mm}$ ) placed in plastic culture dishes. The coverslips were incubated at $18^{\circ} \mathrm{C}$ for $30 \mathrm{~min}$. Non-adherent hemocytes were removed by gently washing the preparations three times with $3 \mathrm{ml}$ of ASW (Zampini et al., 2003).

To obtain hemolymph serum (i.e., hemolymph free of cells), the whole hemolymph was centrifuged at $50 \times g$ for $10 \mathrm{~min}$; the supernatant was then passed through a filter (pore size, $0.22 \mu \mathrm{m}$ ).

\section{ADHESION TO AND ASSOCIATION WITH HEMOCYTE MONOLAYERS}

Evaluation of bacterial adherence to hemocytes was performed as follow: aliquots $(1.5 \mathrm{ml})$ of either ASW or hemolymph serum containing radiolabeled bacteria at a final concentration of $2 \times 10^{7}$ to $3 \times 10^{7}$ bacteria $\mathrm{ml}^{-1}$ were added to monolayers, and the dishes were incubated with gentle shaking at either $4^{\circ} \mathrm{C}$ (to evaluate adhering bacteria) or $18^{\circ} \mathrm{C}$ (to evaluate associated bacteria $=$ adhering + internalized $)$. Triplicate preparations were made for each sample. After 60 min incubation, the cover slips were rinsed with cold ASW, and transferred to PICOFLUOR $^{\mathrm{TM}} 15$ scintillation fluid (Packard Instruments Company Inc., Meriden, CT, USA). For each sample, the number of bacteria per monolayer was calculated using the efficiency of cell labeling. Background counts due to bacterial attachment to coverslips were also evaluated (typically $50-250 \mathrm{cpm}$ ) and subtracted from the sample values. In experiments performed to define the chemical nature of the bacterial component(s) involved in interactions with hemocytes, bacteria were pretreated with pronase $\mathrm{E}$ and sodium meta-periodate. Pronase E was added to bacterial suspensions at a final concentration of $100 \mathrm{pgml}^{-1}$. The suspensions were then incubated for $1 \mathrm{~h}$ at $37^{\circ} \mathrm{C}$ in a shaking water bath and centrifuged. The pellets were resuspended in PBS to the original volume. Sodium meta-periodate pretreatment of bacteria was performed in PBS containing sodium meta-periodate at a final concentration of $1 \mathrm{mM}$. The suspensions were incubated at room temperature for $10 \mathrm{~min}$, washed twice and resuspended in PBS.

\section{BACTERIAL KILLING BY HEMOCYTES}

To evaluate bacterial sensitivity to killing by hemocytes, V. cholerae suspensions (about $10^{7}$ bacteria $\mathrm{ml}^{-1}$ ) were added to hemocyte monolayers at $18^{\circ} \mathrm{C}$ in the presence of hemolymph serum as described above. Triplicate preparations were made for each sampling time. Immediately after the inoculum $(T=0)$ and after $60 \mathrm{~min}$ of incubation at $18^{\circ} \mathrm{C}$ supernatants were collected from monolayers, and hemocytes were lysed by adding $5 \mathrm{ml}$ of cold distilled water and by $10 \mathrm{~min}$ of agitation. The collected monolayer supernatants and hemocyte lysates were pooled and 10-fold serially diluted in PBS; aliquots $(100 \mu \mathrm{l})$ of the diluted samples were plated onto LB agar, and after overnight incubation at $37^{\circ} \mathrm{C}$ the number of colony-forming units (CFU) per milliliter in the hemocyte monolayer (representing culturable bacteria survived to hemocyte bactericidal activity) was determined. Percentages of killing at $60 \mathrm{~min}$ were then determined relative to values obtained at $T=0$. To evaluate the presence of endogenous bacteria in 
hemocytes, controls were performed with hemocyte monolayers without bacteria. The number of CFU in controls never exceeded $0.1 \%$ of those enumerated in experimental samples. To detect and correct for bacterial growth in hemolymph serum, separate samples were seeded with bacteria and $1.5 \mathrm{ml}$ of sterile hemolymph serum. No appreciable bacterial growth was observed at the same time intervals used in killing experiments.

\section{SERUM FRACTIONATION}

Serum was fractionated into low and high molecular mass fractions (LMM and HMM) by ultrafiltration using the Vivaflow 200 complete system (Vivascience AG, Feodor-Lynen-Strasse 21, 30625 Hannover, Germany) comprising a pump (240 V), tubing, $500 \mathrm{ml}$ sample/diafiltration reservoir, and a membrane 5,000 MWCO PES for ultradiafiltration (Vivascience). The LMM 5000 cutoff was chosen since electrophoretic separation of mussel soluble serum proteins (in both 1D and also 2D gels used for proteomic studies in different conditions) generally yields protein bands with MM generally $\geq 10,000$. A diafiltrate, i.e., a LMM containing all the compounds with molecular masses less than $5000 \mathrm{Da}$, and a retentate, i.e., a HMM containing all the compounds with molecular masses greater than $5000 \mathrm{Da}$ were obtained and, after restoring the initial volume, were tested.

\section{STATISTICS}

Experiments were repeated at least three times. Data shown in the Figures are the mean values \pm standard deviation obtained in one representative experiment performed in triplicate. Data were analyzed for significance by the Mann-Whitney $U$ test. Differences were considered significant at $P<0.05$.

\section{RESULTS}

\section{IN VITRO INTERACTIONS OF Vibrio STRAINS WITH HEMOCYTES AND SENSITIVITY TO KILLING}

We studied interactions with hemocytes of $V$. cholerae strains that either do not carry the msha gene (RC60, RC66, and RC69 [nonO1/O139 serogroups]) or do not express it (CD81 [O1 serogroup, classical biotype]). Bacteria were added to hemocyte monolayers in both ASW and hemolymph serum at $18^{\circ} \mathrm{C}$. At this temperature, the number of associated (adhering + internalized) bacteria was evaluated. Figure 1 shows that in hemolymph serum the association efficiency of the tested strains was 2.2-3.5-fold higher than in ASW $(P \leq 0.05)$.

To clarify to what extent the observed differences in association were due to different adhesion efficiencies, the same assays were performed at $4^{\circ} \mathrm{C}$, a condition that almost completely inhibits the internalization process (Zampini et al., 2003; Figure 1). The presence of hemolymph serum increased the number of vibrios adhering to hemocytes by 2.1-2.6-fold in comparison to ASW $\left(P \leq 0.05\right.$; Figure 1). Moreover, as expected, at $4^{\circ} \mathrm{C}$ the number of bacteria interacting with hemocytes was lower than that at $18^{\circ} \mathrm{C}$. Interestingly, the increase in both association with and adherence to mussel hemocytes of the tested strains was about twofold lower than that observed with the MSHA-positive V. cholerae N16961 strain, used for comparison.

Vibrio cholerae strains were then tested for their ability to resist to killing by hemocytes, both in the presence and in the absence
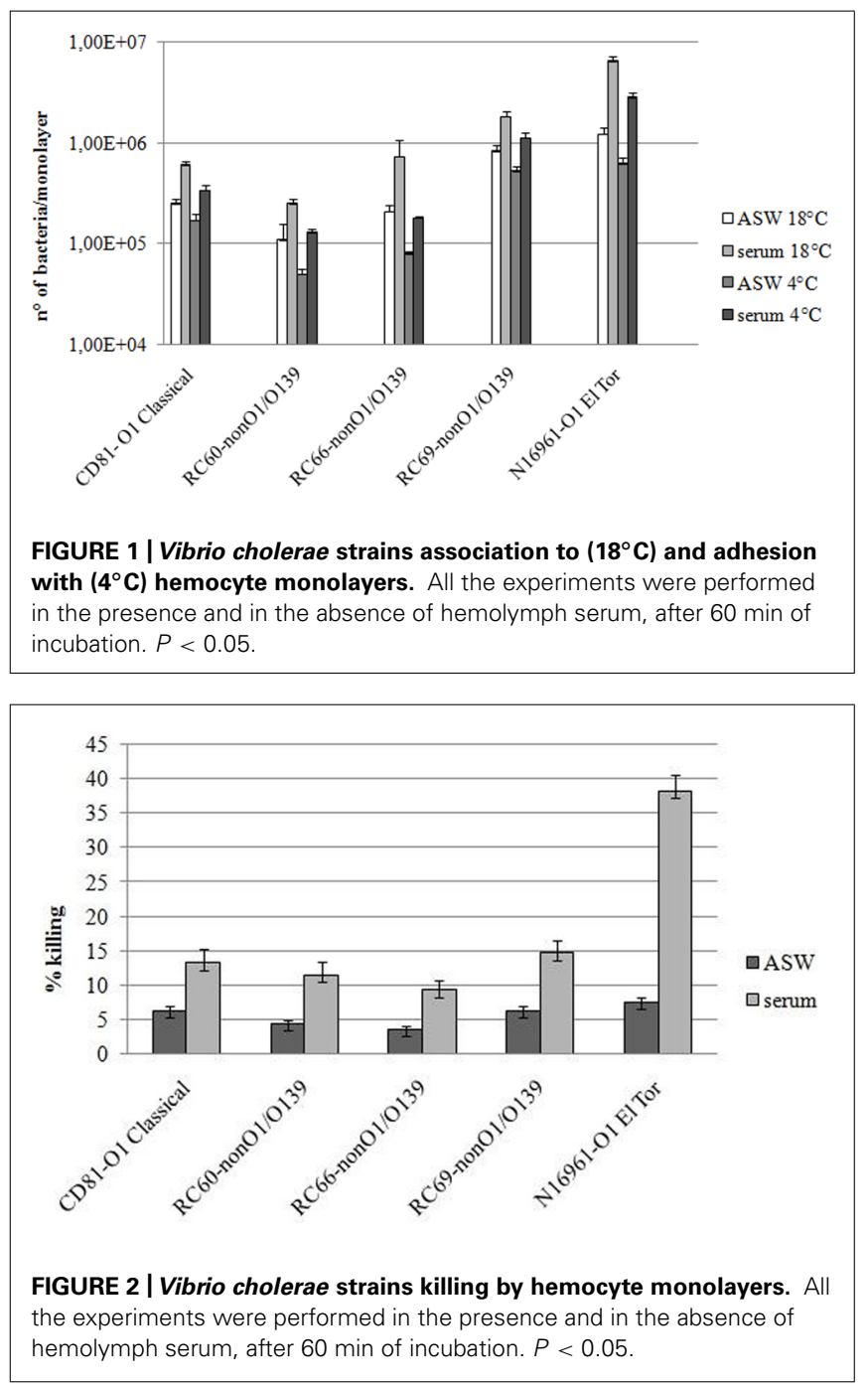

of serum (Figure 2). It was found that, after $60 \mathrm{~min}$ incubation, the percentage of killed bacteria compared to that at $T=0$ ranged from 9.3 to $14.7 \%$ in the experiments performed in serum and from 3.5 to $6.3 \%$ in experiments performed in ASW. Differences between the two experimental conditions were statistically significant $(P \leq 0.05)$. As for association and adhesion, the serummediated increase in killing efficiency of the tested strains by hemocytes was about twofold lower than that observed with $V$. cholerae N16961 strain carrying the MSHA.

As a whole, these results indicate that mussel serum, in addition to opsonins directed toward MSHA, contains factors that mediate binding between Vibrio cell wall component(s) and hemocyte surface receptor(s), and promote internalization and killing of these bacteria.

\section{PRELIMINARY ANALYSIS OF BACTERIAL SURFACE LIGANDS AND SERUM COMPONENTS INVOLVED IN INTERACTIONS OF Vibrio STRAINS WITH HEMOCYTES}

In a first attempt to define the chemical nature of bacterial surface components involved in V. cholerae interactions with hemolymph, adhesion to hemocytes of the tested strains in the presence of 


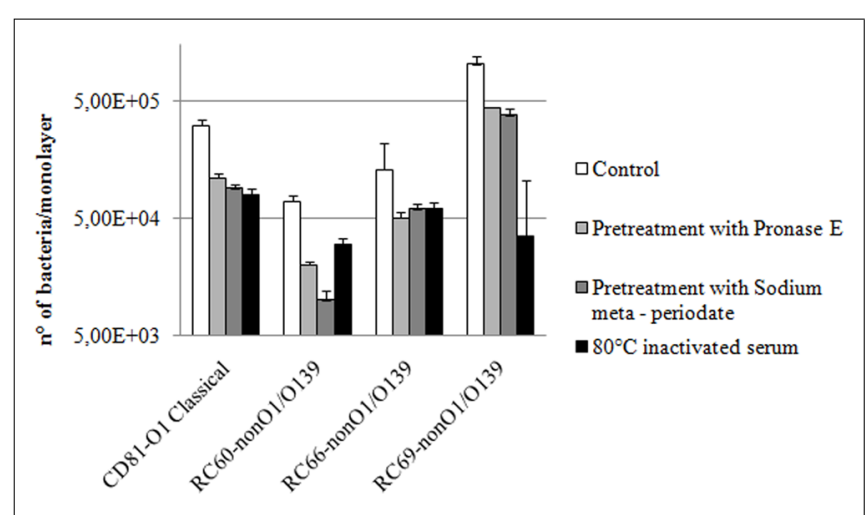

FIGURE 3 | Effect of bacterial pre-treatment with pronase E or sodium meta-periodate and serum heat inactivation on $V$. cholerae strains adhesion to hemocyte monolayers $\left(4^{\circ} \mathrm{C}\right)$ in serum, after $60 \mathrm{~min}$ of incubation. $P<0.05$.

serum was evaluated after bacteria had been treated with either pronase E or sodium meta-periodate, which oxidizes polysaccharides. As shown in Figure 3, both treatments caused a decrease in serum-mediated attachment to hemocytes. In comparison to untreated controls, pronase $\mathrm{E}$ and sodium meta-periodate treatments reduced the interactions by $2.3-3.5$ and $2.7-7.0$-fold, respectively. Meta-periodate oxidation and pronase $\mathrm{E}$ digestion did not affect bacterial viability, as demonstrated by viable counts (data not shown).

To preliminarily assess the main chemical properties of serum factors capable to promote Vibrio strain interactions with hemocytes, hemolymph serum was first exposed $(15 \mathrm{~min})$ to different temperatures, ranging from 45 to $80^{\circ} \mathrm{C}$, then used in experiments to evaluate efficiency of bacterial adhesion to hemocytes. Serum progressively lost its capability to promote $V$. cholerae attachment to hemocytes with increasing temperature from 45 to $80^{\circ} \mathrm{C}$. In particular, the number of bacteria adhering to hemocytes in the presence of serum incubated at $80^{\circ} \mathrm{C}$ was 2.2-3.9-fold lower than that observed in the presence of untreated serum (Figure 3), and similar to those obtained in experiments performed in ASW (Figure 1).

Serum was then fractionated into LMM and HMM fractions by ultrafiltration (see Methods). LMM fraction contained all the compounds with molecular masses lower than 5000 Da, and HMM contained all the compounds with molecular masses greater than $5000 \mathrm{Da}$. Capability of both fractions to promote adhesion to and association with hemocytes of the tested bacteria was analyzed. As shown in Figure 4, whereas LMM fraction did not cause any statistically significant increase in bacterial interactions with hemocytes, the HMM fraction caused a 1.6-2.4-fold increase of both adhesion to and association with monolayers of the tested strains. When the experiments were performed using a mixture of both LMM and HMM fractions, results similar to those obtained with HMM alone were obtained (not shown).

\section{DISCUSSION}

We previously showed that M. galloprovincialis hemolymph serum contains soluble factors that are involved in D-mannose-sensitive interactions between hemocytes and V. cholerae O1 El Tor carrying

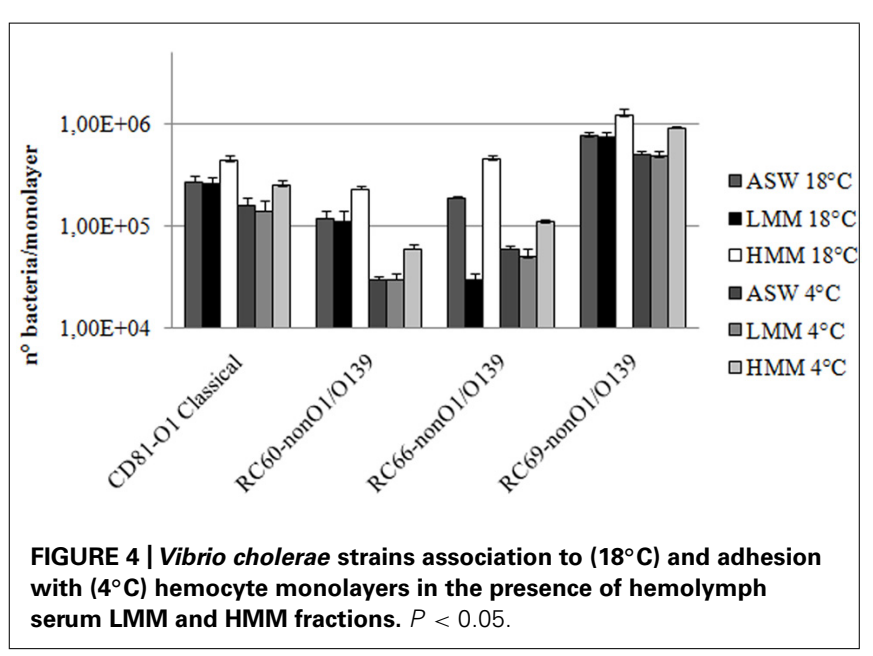

the MSHA adhesin (Zampini et al., 2003). These opsonins enhance phagocytosis and killing of these bacteria by facilitating their binding to hemocytes.

However, other $V$. cholerae strains, including human epidemic clones (O1 classical), not carrying the MSHA ligand are present in coastal waters (Pruzzo et al., 2005b; Oliver et al., 2013) and can be entrapped by mussels. These vibrios, which can persist and replicate in bivalves, were selected for the current study to evaluate if additional serum factors, different from those directed toward MSHA, can affect $V$. cholerae adhesion to hemocytes and sensitivity to killing, modulating its densities inside mussels.

By comparing interactions of $\mathrm{O} 1$ classical and non-O1/O139 strains with hemocytes in ASW and serum, it was found that $M$. galloprovincialis serum actually contains components that promote adhesion to, association with and killing by hemocytes of bacteria that do not carry the MSHA. Serum components different from those acting toward MSHA are likely to be involved as suggested by the fact that serum-mediated increase in bacterial interactions with hemocytes is higher toward V. cholerae $\mathrm{O} 1 \mathrm{El}$ Tor (carrying MSHA) than toward the other tested vibrios (without MSHA). Interestingly, when comparing efficiencies of interactions with hemocytes and killing sensitivity of the different tested strains, a variability among MSHA-negative isolates was observed. This might be due, at least in part, to differences in bacterial surface hydrophobicity and/or surface charge. Moreover, the most adhesive strains might carry surface molecules mediating non-opsonic interactions with hemocyte membrane.

The preliminary analysis of the chemical nature of the involved bacterial ligand(s) indicated that both cell wall protein(s) and carbohydrate(s) are responsible for the interactions of non-El Tor $V$. cholerae strains with serum. In fact, using vibrios pre-treated with proteinase E or sodium meta-periodate that disrupts cell surface polysaccharide, the observed serum-mediated increase of adhesion and association showed a significant reduction in comparison to untreated controls. On the other hand, the fact that serum exposure to high temperature $\left(80^{\circ} \mathrm{C}\right)$ abolished its capability to promote adhesion to and association with phagocytes suggests that heat-sensitive serum components are involved in the opsonizing activity. Experiments conducted with HMM and LMM fractions 
obtained by serum ultrafiltration indicate that these compounds have molecular mass higher than $5000 \mathrm{Da}$.

Further studies are needed to define the chemical nature and specificity of both the involved bacterial adhesins and hemolymph opsonins as well as physical and chemical conditions promoting or inhibiting such interactions inside bivalves in vivo. This information will be crucial to better understand the strategies used by mussels to control bacterial diffusion in their tissues and by $V$. cholerae to persist and spread in the aquatic environment.

Consumption of raw or partially cooked bivalves has been implicated in numerous food poisoning outbreaks. Thus, their microbial flora is of great concern to public health (Suzita et al., 2009; Scallan etal., 2011). The ability of bivalves to eliminate pathogens from their tissues is due, at least in part, to the ability of hemocytes to bind, phagocytize, and kill these bacteria (Canesi et al., 2002; Pruzzo et al., 2005a). Deciphering molecular mechanisms affecting pathogenic bacteria - hemocytes interactions represents the basis to improve depuration treatment and to prevent transmission of pathogens to humans through consumption of raw or partially cooked bivalves. As an example, to reduce the load of unwanted bacteria inside bivalves, depuration might be conducted in conditions that favor phagocytosis of pathogens and their clearance from hemolymph.

Unraveling the cellular and molecular mechanisms associated with hemolymph anti-bacterial activity is also central to understand the pathogenesis of bivalve diseases in cultured and wild populations of species susceptible to Vibrio spp. infection, and to set up new strategies to control summer mortalities affecting the bivalve production (e.g., Crassostrea gigas oysters) in aquaculture worldwide (Gay et al., 2004; Garnier et al., 2007).

\section{ACKNOWLEDGMENTS}

This work was supported by grants from Italian Ministry of Education and Research (MIUR, PRIN 2008) and Genova University (Italy).

\section{AUTHOR CONTRIBUTIONS}

Laura Canesi and Luigi Vezzulli organized and performed most experiments. Chiara Grande and Margherita Bavestrello took care of aspects related to mussel maintenance in aquarium and hemocyte monolayer preparations. Elisabetta Pezzati cultured and controlled bacterial strains. Monica Stauder supplied technical assistance. Adele Papetti carried out serum fractionation. Carla Pruzzo designed the experiments and supervised.

\section{REFERENCES}

Balbi, T., Fabbri, R., Cortese, K., Smerilli, A., Ciacci, C., Grande, C., et al. (2013). Interactions between Mytilus galloprovincialis hemocytes and the bivalve pathogens Vibrio aestuarianus 01/032 and Vibrio splendidus LGP32. Fish Shellfish Immunol. doi: 10.1016/j.fsi.2013.09.027 [Epub ahead of print].

Beleneva, I. A., Zhukova, N. V., Le Lan, H., and Nqueyen Tran, D. H. (2007). Taxonomic composition of bacteria associated with cultivated mollusks Crassostrea lugubris and Perna viridis and with the water of the Gulf of Nha Trang lagoon, Vietnam. Mikrobiologiia 76, 253-262.

Canesi, L., Betti, M., Ciacci, C., Lorusso, L. C., Gallo, G., and Pruzzo, C. (2005). Interactions between Mytilus haemocytes and different strains of Escherichia coli and Vibrio cholerae $\mathrm{O} 1 \mathrm{El}$ Tor: role of kinase-mediated signalling. Cell. Microbiol. 7, 667-674. doi: 10.1111/j.1462-5822.2005.00499.x
Canesi, L., Gavioli, M., Pruzzo, C., and Gallo, G. (2002). Bacteria-hemocyte interactions and phagocytosis in marine bivalves. Microsc. Res. Tech. 57, 469-476. doi: 10.1002/jemt.10100

Chiavelli, D. A., Marsh, J. W., and Taylor, R. K. (2001). The mannose-sensitive hemagglutinin of Vibrio cholerae promotes adherence to zooplankton. Appl. Environ. Microbiol. 67, 3220-3225. doi: 10.1128/AEM.67.7.3220-3225.2001

Duperthuy, M., Schmitt, P., Garzón, E., Caro, A., Rosa, R. D., Le Roux, F., etal. (2011). Use of OmpU porins for attachment and invasion of Crassostrea gigas immune cells by the oyster pathogen Vibrio splendidus. Proc. Natl. Acad. Sci. U.S.A. 108, 2993-2998. doi: 10.1073/pnas. 1015326108

Garnier, M., Labreuche, Y., Garcia, C., Robert, M., and Nicolas, J. L. (2007). Evidence for the involvement of pathogenic bacteria in summer mortalities of the Pacific oyster Crassostrea gigas. Microb. Ecol. 53, 187-196. doi: 10.1007/s00248-0069061-9

Gay, M., Berthe, F. C. J., and Le Roux, F. (2004). Screening of Vibrio isolates to develop an experimental infection model in the Pacific oyster, Crassostrea gigas. Dis. Aquat. Organ. 59, 49-56. doi: 10.3354/dao059049

Harris-Young, L., Tamplin, M. L., Mason, W. J., Aldrich, H. C., and Jackson, K. (1995). Viability of Vibrio vulnificus in association with hemocytes of the American oyster (Crassostrea virginica). Appl. Environ. Microbiol. 61, 52-57.

Iwamoto, M., Ayers, T., Mahon, B. E., and Swerdlow, D. L. (2010). Epidemiology of seafood-associated infections in the United States. Clin. Microbiol. Rev. 23, 399-411. doi: 10.1128/CMR.00059-09

Kaper, J. B., Morris, J. G. Jr., and Levine M. M. (1995). Cholera. Clin. Microbiol. Rev. $8,48-86$.

Lipp, E. K., Huq, A., and Colwell, R. R. (2002). Effects of global climate on infectious disease: the cholera model. Clin. Microbiol. Rev. 15, 757-770. doi: 10.1128/CMR.15.4.757-770.2002

Murphree, R. L., and Tamplin, M. L. (1995). Uptake and retention of Vibrio cholerae in the eastern oyster, Crassostrea virginica. Appl. Environ. Microbiol. 61, 36563660

Nelson, E. J., Harris, J. B., Morris, J. G. Jr., Calderwood, S. B., and Camilli, A. (2009). Cholera transmission: the host, pathogen and bacteriophage dynamic. Nat. Rev. Microbiol. 7, 693-702 doi: 10.1038/nrmicro2204

Oliver, J. D., Pruzzo, C., Vezzulli, L., and Kaper, J. B. (2013). “Vibrio species,” in Food Microbiology: Fundamentals and Frontier, eds M. P. Doyle and R. L. Buchanan (Washington: ASM Press), 401-439.

Pruzzo, C., Gallo, G., and Canesi, L. (2005a). Persistence of vibrios in marine bivalves: the role of interactions with hemolymph components. Environ. Microbiol. 7, 761-772. doi: 10.1111/j.1462-2920.2005. 00792.x

Pruzzo, C., Huq, A., Colwell, R.R., and Donelli, G. (2005b). "Pathogenic Vibrio species in marine and estuarine environment," in Oceans and Health: Pathogens in the Marine Environment eds R. R. Colwell and S. Belkin (New York: Kluwer Academic/Plenum Publishers), 217-252.

Scallan, E., Hoekstra, R. M., Angulo, F. J., Tauxe, R. V., Widdowson, M. A., Roy, S. L., etal. (2011). Foodborne illness acquired in the United States-major pathogens. Emerg. Infect. Dis. 17, 7-15. doi: 10.3201/eid1701. P21101

Suzita, R., Abdulamir, A. S., Bakar, F. A., and Son, R. (2009). A mini review: cholera outbreak via shellfish. Am. J. Infect. Dis. 5, 40-47. doi: 10.3844/ajidsp.2009.40.47

Tamplin, M. L., and Capers, G. M. (1992). Persistence of Vibrio vulnificus in tissues of Gulf Coast oysters, Crassostrea virginica, exposed to seawater disinfected with UV light. Appl. Environ. Microbiol. 58, 1506-1510.

Teplitski, M., Wright, A. C., and Lorca, G. (2009). Biological approaches for controlling shellfish-associated pathogens. Curr. Opin. Biotechnol. 20, 185-190. doi: 10.1016/j.copbio.2009.03.001

Vazquez-Novelle, M. D., Pazos, A. J., Abad, M., Sanchez, J. L., and Perez-Paralle, M. L. (2005). Eight-hour PCR-based procedure for the detection of Salmonella in raw oysters. FEMS Microbiol. Lett. 243, 279-283. doi: 10.1016/j.femsle.2004. 12.016

Zampini, M., Canesi, L., Betti, M., Ciacci, C., Tarsi, R., Gallo, G., et al. (2003). Role for mannose-sensitive hemagglutinin in promoting interactions between Vibrio cholerae El Tor and mussel hemolymph. Appl. Environ. Microbiol. 69, 5711-5715. doi: 10.1128/AEM.69.9.5711-5715.2003 
Conflict of Interest Statement: The authors declare that the research was conducted in the absence of any commercial or financial relationships that could be construed as a potential conflict of interest.

Received: 09 October 2013; paper pending published: 29 October 2013; accepted: 20 November 2013; published online: 09 December 2013.

Citation: Canesi L, Pezzati E, Stauder M, Grande C, Bavestrello M, Papetti A, Vezzulli L and Pruzzo C (2013) Vibrio cholerae interactions with Mytilus galloprovincialis hemocytes mediated by serum components. Front. Microbiol. 4:371. doi: 10.3389/fmicb.2013.00371
This article was submitted to Aquatic Microbiology, a section of the journal Frontiers in Microbiology.

Copyright (C) 2013 Canesi, Pezzati, Stauder, Grande, Bavestrello, Papetti, Vezzulli and Pruzzo. This is an open-access article distributed under the terms of the Creative Commons Attribution License (CC BY). The use, distribution or reproduction in other forums is permitted, provided the original author(s) or licensor are credited and that the original publication in this journal is cited, in accordance with accepted academic practice. No use, distribution or reproduction is permitted which does not comply with these terms. 